\title{
POSTUPANJE OMBUDSMENA ZA LJUDSKA PRAVA BOSNE I HERCEGOVINE U PREDMETIMA DISKRIMINACIJE
}

Sažetak: Ombudsmeni za ljudska prava ili nacionalne institucije za zaštitu ljudskih prava u većini savremenih zemalja svijeta danas predstavljaju nezavisne institucije koje su uspostavljene radi promocije dobre uprave i vladavine prava, odnosno zaštite ljudskih prava i osnovnih sloboda. U njihovoj nadležnosti su, u pravilu, zaštita $i$ promocija ljudskih prava i sloboda, kao i funkcionisanje nacionalnih preventivnih mehanizama za prevenciju i sprečavanje torture i drugih surovih, neljudskih ili ponižavajućih kazni ili postupaka. Pored toga, uz manje ili značajnije razlike, ove institucije imaju u svojoj nadležnosti i postupanja u predmetima koji se odnose na slobodu pristupa informacijama te ministarska, vladina i druga imenovanja.

Važan segment njihovog djelovanja svakako jeste i sprečavanje, odnosno eliminacija diskriminacije. Diskriminacija (od riječi discriminare: odvajati, praviti razliku, neopravdano pravljenje razlike ili nejednako postupanje, odnosno nedozvoljeno razlikovanje) predstavlja negativnu i društveno opasnu pojavu koja najkraće rečeno podrazumijeva svako nejednako ili različito postupanje uključujući svako isključivanje, ograničavanje ili davanje prednosti utemeljeno na stvarnim ili pretpostavljenim osnovama prema bilo kojem licu ili grupi lica, i onima koji su s njima u rodbinskoj ili drugoj vezi, na osnovu njihove rase, boje kože, jezika, vjere, etničke pripadnosti, invaliditeta, starosne dobi, nacionalnog ili socijalnog porijekla, političkog ili drugog uvjerenja, imovnog stanja, članstva u sindikatu ili drugom udruženju, obrazovanja, društvenog položaja i pola, polnog izražavanja ili orijentacije, kao i svake druge okolnosti koja ima za svrhu ili posljedicu da bilo kojem licu onemogući ili ugrožava priznavanje, uživanje ili ostvarivanje na ravnopravnoj osnovi, prava i sloboda u svim oblastima života.

Upravo o načinu postupanja nacionalnih organa za zaštitu ravnopravnosti, odnosno prije svih Ombudsmena za ljudska prava Bosne i Hercegovine $u$ postupcima diskriminacije biće riječi u ovom referatu.

Ključne riječi: $\quad$ ljudska prava i slobode, diskriminacija, Ombudsmen za ljudska prava Bosne i Hercegovine, nezavisnost rada, žalba, postupak za zaštitu od diskriminacije.

\footnotetext{
* $\quad$ Dr. sc. Ljubinko Mitrović, redovni profesor na Fakultetu pravnih nauka Univerziteta APEIRON u Banjoj Luci i Obmudsmen za ljudska prava Bosne i Hercegovine, Jovana Surutke br. 13, 78000 Banja Luka. Adresa e-pošte: lj.mitrovic@ombudsmen.gov.ba., ljubinko58@gmail.com ORCID: https://orcid.org/0000-0002-3809-4183.
} 


\section{UVOD}

Diskriminacija kao izuzetno negativna društvena pojava je zabranjena svim domaćim, ali i međunarodnim pravnim dokumentima ${ }^{1}$ (i standardima zaštite ljudskih prava u njima) koji su na snazi u Bosni i Hercegovini. Naime, diskriminacija je zabranjena u odredbama najvišeg pravnog akta u Bosni i Hercegovini, odnosno u Ustavu Bosne i Hercegovine ${ }^{2}$ (ali i u ustavima entiteta, Statutu Brčko distrikta, ustavima kantona), kao i u svim zakonima koji uređuju pojedine oblasti života i rada čovjeka, odnosno građanina (u oblasti rada, zdravlja, obrazovanja, socijalne zaštite i sl.).

Donošenjem Zakona o zabrani diskriminacije Bosne i Hercegovine $e^{3}$ u julu 2009. godine, $u$ Bosni i Hercegovini su jasno definisani svi oblici diskriminacije ${ }^{4}$, ali i institucije nadležne za zaštitu od diskriminacije ${ }^{5}$, kao i instrumenti, odnosno postupci za zaštitu od diskriminacije.

1 Posebno su važne tzv. nediskriminacijske direktive Evropske unije, i to: Council Directive 2000/43/EC of 29 June 2000 implementing the principle of equal treatment between persons irrespective of racial or ethnic origin, Official Journal of the European Union, $\mathrm{L}$ 18/2000, recital 24 Preambule i član 13; Council Directive 2004/113/EC of 13 December 2004 implementing the principle of equal between men and women in the access to and supply of goods and services, Official Journal of the European Union, L 373/2004, član 12; Directive 2006/51/EC of the European parliament and of the Council of 5 July 2006 on the implementattion of the principle of equal opportunities and equal treatment of men and women in matters of employment and occupation (recast), Official Journal of the European Union, L 204/2006, član 20. Pored njih: Povelja Ujedinjenih nacija, Univerzalna deklaracija o ljudskim pravima, Pakt o građanskim i političkim pravima, Konvencija o ukidanju svih oblika rasne diskriminacije, Evropska konvencija za zaštitu ljudskih prava i osnovnih sloboda...

2 Ustav Bosne i Hercegovine.

3 Službeni glasnik Bosne i Hercegovine, broj 59/2009 i 66/2016.

4 Neposredna diskriminacija; posredna diskriminacija; uznemiravanje; seksualno uznemiravanje; mobing; segregacija; izdavanje naloga drugima za vršenje diskriminacije i pomaganje drugima prilikom diskriminacije; podsticanje na diskriminaciju. Težim oblikom diskriminacije smatraće se diskriminacija počinjena prema određenom licu po više osnova iz člana 2 stav (1) ovog zakona (višestruka diskriminacija), diskriminacija počinjena više puta (ponovljena diskriminacija) i diskriminacija koja postoji duže vrijeme (produžena diskriminacija).

5 Odredbe člana 7 Zakona o zabrani diskriminacije koji nosi naslov: Centralna institucija za zaštitu od diskriminacije glase: (1) Centralna institucija nadležna za zaštitu od diskriminacije je Ombudsmen za ljudska prava Bosne i Hercegovine (u daljnjem tekstu: Ombudsmen Bosne i Hercegovine). (2) Ombudsmen Bosne i Hercegovine postupa u skladu sa ovim zakonom i Zakonom o ombudsmenu za ljudska prava $\mathrm{BiH}$ na način da: a) zaprima pojedinačne i grupne žalbe u vezi sa diskriminacijom; b) fizičkim i pravnim licima koje su podnijele žalbu zbog diskriminacije pruža potrebna obavještenja o njihovim pravima i obavezama, te mogućnostima sudske i druge zaštite; c) povodom žalbe Ombudsmen Bosne i Hercegovine može da odluči da ne prihvati žalbu ili da pokrene istražni postupak u skladu sa posebnim propisima; d) predlaže pokretanje postupka medijacije u skladu s odredbama Zakona o medijaciji; e) prikuplja i analizira statističke podatke o slučajevima diskriminacije; f) podnosi godišnji, a prema potrebi i vanredne izvještaje o pojavama diskriminacije Parlamentarnoj skupštini Bosne i Hercegovine, Parlamentu Federacije Bosne i Hercegovine, Narodnoj skupštini Republike Srpske i Skupštini Brčko Distrikta Bosne i Hercegovine; g) informiše javnost o pojavama diskriminacije; $\mathrm{h}$ ) na sopstvenu inicijativu sprovodi istraživanja u oblasti diskriminacije; i) daje mišljenja i preporuke s ciljem sprečavanja i suzbijanja diskriminacije, te predlaže odgovarajuća zakonska i druga rješenja nadležnim institucijama Bosne i Hercegovine; j) ima pravo da pokreće i učestvuje u postupku za zaštitu od diskriminacije za prekršaje propisane ovim zakonom; k) prati zakonodavstvo i daje savjete zakonodavnim i izvršnim organima; l) radi na promociji ovog zakona, informiše javnost, podiže svijest, sprovodi kampanje i na druge načine aktivno promoviše borbu protiv diskriminacije u svrhu njene prevencije; $\mathrm{m}$ ) unapređuje politike i prakse koje imaju za cilj da osiguraju jednako postupanje. (3) Ombudsmen Bosne i Hercegovine pri izradi redovnih izvještaja, mišljenja i preporuka o pojavama diskriminacije sarađuje sa organizacijama civilnog društva koje se bave zaštitom i promovisanjem ljudskih prava i organizacijama koje se bave zaštitom prava grupa izloženih visokom riziku diskriminacije. (4) Ombudsmen Bosne i Hercegovine pruža pomoć licima ili grupama lica koje se obraćaju međunarodnim tijelima za zaštitu od diskriminacije u davanju uputa, savjeta, konsultacija u toku postupka, prijedloga i preporuka. (5) Institucija ombudsmena za ljudska prava Bosne i Hercegovine će u svrhu ostvarivanja svoje nadležnosti uspostaviti poseban odjel koji bi isključivo razmatrao predmete navodne diskriminacije u pogledu postupanja javnih tijela na nivou države, entiteta, kantona i Brčko Distrikta Bosne i Hercegovine, opštinskih institucija i tijela, te pravnih lica s javnim ovlašćenjima, kao i postupanje svih pravnih i fizičkih lica, u svim oblastima života. U budžet Institucije ombudsmena za ljudska prava Bosne i Hercegovine uvrstiće se posebna budžetska stavka neophodna za funkcionisanje specijalnog odjela/specijalnih odjela za borbu protiv diskriminacije. (6) Sve državne institucije, entitetske, kantonalne i tijela Brčko Distrikta Bosne i Hercegovine, opštinska, institucije i pravna lica s javnim ovlašćenjima, te ostala pravna i fizička lica dužna su, na zahtjev Ombudsmena Bosne i Hercegovine, najkasnije 
Tako, Zakon o zabrani diskriminacije Bosne i Hercegovine predviđa nekoliko postupaka za zaštitu od diskriminacije, i to: postupak pred Institucijom ombudsmena za ljudska prava BiH, sudske postupke i upravne postupke. ${ }^{6}$

Pojam diskriminacije, shodno Zakonu o zabrani diskriminacije Bosne i Hercegovine, odnosi se na zakonom uređeno konfliktno ponašanje koje sadrži zakonom utvrđene elemente. ${ }^{7}$ Zakon definiše elemente diskriminacije na osnovu definicija iz međunarodnih sporazuma $u$ oblasti ljudskih prava, ali i u skladu sa praksom Ujedinjenih nacija, Evropskog suda za ljudska prava i direktivama Evropske unije.

\section{O POSTUPCIMA PRED NACIONALNIM ORGANIMA ZA ZAŠTITU RAVNOPRAVNOSTI}

Postupci pred institucijama (uredima ili kancelarijama) ombudsmena za ljudska prava nisu u našoj praksi i na našim prostorima uobičajeni poput upravnih, parničnih, krivičnih, prekršajnih ili disciplinskih postupaka. Naime, njihova posebnost, odnosno specifičnost se izvodi, prije svega iz specifičnosti institucija koje ih sprovode, odnosno prije svih institucija ombudsmena za ljudska prava, odnosno povjerenika za zaštitu ravnopravnosti. ${ }^{8} \mathrm{U}$ tom

u roku od 30 dana od dana zaprimanja zahtjeva dostaviti tražene podatke i dokumente. (7) Nadležne institucije u Bosni i Hercegovini obavezne su da sarađuju sa Ombudsmenom Bosne i Hercegovine i daju pismeno odgovore i obavještenja u roku koji je Ombudsmen Bosne i Hercegovine odredio i o efektu preporuka datih s ciljem otklanjanja diskriminacije.

6 Trnavci, G.; Bešlagić, J., Specifičnosti sudskih postupaka za zaštitu od diskriminacije u Bosni i Hercegovini, Pravni vjesnik, god. 31, br. 3-4, Pravni fakultet u Osijeku, 2015.

7 Diskriminacijom, u smislu ovog zakona, smatraće se svako različito postupanje, uključujući svako isključivanje, ograničavanje ili davanje prednosti utemeljeno na stvarnim ili pretpostavljenim osnovama prema bilo kojem licu ili grupi lica i onima koji su s njima u rodbinskoj ili drugoj vezi na osnovu njihove rase, boje kože, jezika, vjere, etničke pripadnosti, invaliditeta, starosne dobi, nacionalnog ili socijalnog porijekla, veze s nacionalnom manjinom, političkog ili drugog uvjerenja, imovnog stanja, članstva u sindikatu ili drugom udruženju, obrazovanja, društvenog položaja i pola, seksualne orijentacije, rodnog identiteta, polnih karakteristika, kao i svaka druga okolnost koja ima za svrhu ili posljedicu da bilo kojem licu onemogući ili ugrožava priznavanje, uživanje ili ostvarivanje na ravnopravnoj osnovi prava i sloboda u svim oblastima javnog života.

8 U Srbiji, to je Poverenik za zaštitu ravnopravnosti (Poverenik: prima i razmatra pritužbe zbog povreda odredaba Zakona o zabrani diskriminacije i daje mišljenja i preporuke u konkretnim slučajevima i izriče mere u skladu sa članom 40. ovog zakona; podnosiocu pritužbe pruža informacije o njegovom pravu i mogućnosti pokretanja sudskog ili drugog postupka zaštite, odnosno preporučuje postupak mirenja; podnosi tužbe iz člana 43. ovog zakona, zbog povrede prava iz ovog zakona, u svoje ime a uz saglasnost i za račun diskriminisanog lica, ukoliko postupak pred sudom po istoj stvari nije već pokrenut ili pravnosnažno okončan; podnosi prekršajne prijave zbog povrede prava iz ovog zakona; podnosi godišnji i poseban izveštaj Narodnoj skupštini o stanju u oblasti zaštite ravnopravnosti; upozorava javnost na najčešće, tipične i teške slučajeve diskriminacije; prati sprovođenje zakona i drugih propisa, inicira donošenje ili izmenu propisa radi sprovođenja i unapređivanja zaštite od diskriminacije i daje mišljenje o odredbama nacrta zakona i drugih propisa koji se tiču zabrane diskriminacije; uspostavlja i održava saradnju sa organima nadležnim za ostvarivanje ravnopravnosti i zaštitu ljudskih prava na teritoriji autonomne pokrajine i lokalne samouprave; preporučuje organima javne vlasti i drugim licima mere za ostvarivanje ravnopravnosti), u Hrvatskoj, Pučki pravobranitelj (sa sljedećim nadležnostima: zaprimanje prijava svih fizičkih i pravnih osoba; pružanje potrebnih obavijesti fizičkim i pravnim osobama o njihovim pravima i obvezama te mogućnostima sudske i druge zaštite; ispitivanje pojedinačnih prijava i poduzimanje radnji u okviru nadležnosti, potrebnih za otklanjanje diskriminacije i zaštitu prava diskriminirane osobe (ukoliko nije započet sudski postupak); upozoravanje javnosti na pojave diskriminacije; uz pristanak stranke, provođenje postupka mirenja, uz mogućnost sklapanja izvansudske nagodbe; podnošenje kaznenih prijava u vezi sa slučajevima diskriminacije nadležnom državnom odvjetništvu; prikupljanje i analiza statističkih podataka o slučajevima diskriminacije; izvještavanje Hrvatskog sabora o pojavama diskriminacije, u godišnjem izvješću, a po potrebi i izvanrednim izvješćem; provođenje istraživanja u području diskriminacije, davanje mišljenja i preporuka te predlaganje odgovarajućih zakonskih i strateških rješenja Vladi Republike Hrvatske), u Crnoj Gori, Zaštitnik ljudskih prava i sloboda Crne Gore - Ombudsman (Zaštitnik je institucionalni mehanizam za zaštitu od diskriminacije. Zaštitnik, uz saglasnost diskriminisanog lica, postupa i preduzima mjere za zaštitu od diskriminacije, u skladu sa Zakonom o Zaštitniku i posebnim zakonom kojim je uređena zabrana diskriminacije. U postupanju Zaštitnika u 
smislu, treba istaći da se radi o posebnim organima, odnosno nacionalnim institucijama koje se bave ponajprije promocijom i zaštitom ljudskih prava. Dakle, ove institucije u većini savremenih zemalja svijeta danas predstavljaju nezavisne institucije koje su uspostavljene s ciljem promocije dobre uprave i vladavine prava, odnosno zaštite ljudskih prava i osnovnih sloboda. Pravilo je da se ove institucije osnivaju posebnim zakonima i one, na svojevrstan način predstavljaju korektiv vlasti (jedne, druge, često i treće, odnosno izvršne, sudske, pa i zakonodavne na određeni način). Oblasti u kojima ove institucije danas djeluju tiču se ekonomskih, socijalnih, kulturnih, građanskih, ali i političkih prava, a posebno se bave tzv. ranjivim kategorijama stanovništva, odnosno kršenjima prava djece, osoba sa invaliditetom, starijih osoba, pritvorenika, odnosno osuđenika, te nacionalnih, vjerskih i drugih manjina.

S druge strane, zakonima kojima se osnivaju, u pravilu se uređuju i njihova postupanja u predmetima koji se registruju u ovim institucijama, a tiču se žalbi građana na postupanja organa vlasti. Nekoliko je karakteristika važnih za ove postupke, a tiču se njihove jednostavnosti, ali i besplatnosti (postupak zaštite pred ombudsmenima je posebno prilagođen potrebama siromašnih i marginalizovanih grupa građana), zatim hitnosti u postupanju, odnosno njihove brzine, obrnutog tereta dokazivanja, načina podnošenja pritužbe, odnosno žalbe, podnošenja kolektivnih žalbi, mogućnosti učešća trećih lica u sudskim postupcima, zabrane viktimizacije i posebno donošenja odluka.

\section{3. ŽALBA I NJENO PODNOŠENJE U INSTITUCIJI OMBUDSMENA ZA LJUDSKA PRAVA BOSNE I HERCEGOVINE}

Slično stanje je i sa institucijom Ombudsmena za ljudska prava Bosne i Hercegovine (koju, shodno Zakonu o ombudsmenu za ljudska prava Bosne i Hercegovine ${ }^{9}$ čine tri ombudsmena iz reda tri konstitutivna naroda, Srba, Hrvata i Bošnjaka; u daljnjem tekstu: Institucija) i kojoj je prema Zakonu o zabrani diskriminacije Bosne i Hercegovine ${ }^{10}$ (u daljnjem tekstu: ZZD) povjeren status "centralne institucije nadležne za zaštitu od diskriminacije“. Prema odredbama ZZD-a ombudsmeni imaju niz nadležnosti koje sežu od promotivnih aktivnosti, preko istraživanja u oblasti diskriminacije, do možda i najvažnije nadležnosti, odnosno postupanja po žalbama pojedinaca koji tvrde da su žrtve diskriminacije i preuzimanja aktivne uloge u prekršajnim postupcima za zaštitu od diskriminacije.

Postupak pred ombudsmenima za ljudska prava Bosne i Hercegovine pokreće se podnošenjem žalbe. U tom kontekstu, svi načini obraćanja ombudsmenima su prilagođeni njihovim krajnjim korisnicima, odnosno podnosiocima žalbi. Na podnošenje žalbe ovlašćeni su svako fizičko i pravno lice ili grupa građana koji smatraju da je u odnosu na njih bilo kojim aktom, radnjom ili propuštanjem izvršena diskriminacija po bilo kom osnovu. Ukoliko se radi o povredi prava grupe građana, žalbu u kojoj trebaju biti naznačeni svi podnosioci i predstavnik

slučajevima diskriminacije od strane fizičkih ili pravnih lica shodno se primjenjuju odredbe Zakona o zaštitniku), u Makedoniji, Naroden pravobranitel...

9 Službeni glasnik Bosne i Hercegovine, br. 19/2002, 35/2004 i 32/2006. 
grupe, može podnijeti, uz predstavnika grupe, bilo koje lice iz grupe. Pored toga, uz ispunjenje određenih uslova, postupak mogu pokrenuti i organizacije koje se bave zaštitom ljudskih prava i druga lica, s tim što ukoliko postupak pokreću radi zaštite konkretnog lica, to mogu činiti samo u ime i uz saglasnost tog lica. No, treba svakako zapaziti i činjenicu da značajan broj stranaka koje podnose žalbe nemaju adekvatnu pravnu pomoć (ni pravničko znanje), te da je zbog toga još uvijek neophodno ulagati dodatne napore u pogledu podrške podnosiocima žalbi kako bi oni na što adekvatniji i efikasniji način obrazložili navode svoje žalbe. U tom smislu, podnosioci žalbe mogu se ombudsmenima obraćati na jedan od sljedećih načina, i to:

1) ispunjavanjem obrasca žalbe od strane podnosioca žalbe i njenim dostavljanjem putem redovne pošte, elektronskom poštom (sa skeniranim podneskom i potpisom podnosioca žalbe), u elektronskoj formi uz elektronski potpis podnosioca žalbe, faxom ili predajom na pisarnicu Institucije $\mathrm{i}$

2) ispunjavanjem obrasca žalbe uz pomoć postupajućeg pravnika (pravnika kojem je dodijeljen konkretan predmet).

Najcjelishodniji, odnosno najpraktičniji način pokretanja postupka istraživanja pred Institucijom jeste slanjem popunjenog obrasca žalbe koji je dostupan na internet stranici Institucije ili u bilo kojoj od područnih kancelarija ${ }^{11}$ od strane podnosioca žalbe. Izuzetno, ukoliko se radi o podnošenju žalbe u drugačijoj formi, žalba upućena Instituciji mora biti podnesena u pismenoj formi, na jedan od naprijed pobrojanih načina, ili neposredno predata u prostorijama Institucije, te svakako potpisana.

Kako bi podnosiocima žalbi praktično olakšali ispunjavanje obrasca žalbe, ombudsmeni su prije nekoliko mjeseci izradili i posebne Smjernice za ispunjavanje obrasca žalbe u onim slučajevima kada se građani žale na diskriminaciju.

Ako se radi o neukoj ili nepismenoj stranci ili stranci koja iz bilo kojeg razloga ima poteškoće u pismenom izražavanju, postupajući pravnik dužan je popuniti obrazac žalbe u njeno ime, a prema podacima koji su mu od strane podnosioca žalbe predstavljeni. Ukoliko okolnosti konkretnog slučaja to nalažu (npr. kada se radi o licima koja borave u inostranstvu, odnosno licima koja žele ostati anonimna i sl.), ombudsmeni, odnosno postupajući pravnik razmatraće i žalbe koje su upućene elektronskim putem, s tim što postupajući pravnik može u daljem toku postupka istraživanja tražiti od podnosioca žalbe popunjen i potpisan obrazac žalbe.

Žalba, u pravilu, treba da sadrži:

1) lične podatke o podnosiocu žalbe (radi se o licu koje je diskriminisano), odnosno prezime i ime podnosioca žalbe, njegovo zanimanje, datum rođenja, adresu, i nacionalnost ukoliko podnosilac žalbe želi da se izjasni, pol, datum i mjesto rođenja,

2) podatke o punomoćniku, odnosno kontakt osobi ukoliko takva osoba postoji,

3) podatke o organu na koji se žalba odnosi (radi se o organu od koga je podnosilac žalbe diskriminisan),

11 Pored centralne kancelarije u sjedištu Institucije u Banjoj Luci, organizovane se i funkcionišu i terenske kancelarije u Sarajevu, Mostaru, Brčkom i Livnu. 
4) kratko navođenje činjenica koje ukazuju na povredu prava podnosioca žalbe (način na koji je podnosilac žalbe diskriminisan, odnosno dokaze i navode o dokaznim sredstvima koja se mogu upotrijebiti u cilju dokazivanja istinitosti činjenica vezanih za akt diskriminacije),

5) izjavu žalioca o tome da li je i kada pokrenut postupak kod drugog organa, a u vezi s konkretnim slučajem,

6) izjavu podnosioca žalbe da li on zahtijeva da njegov/njen identitet i okolnosti konkretnog slučaja ostanu u tajnosti,

7) datum podnošenja žalbe i

8) potpis podnosioca žalbe.

Obrazac žalbe svakako sadrži i pouku podnosiocu žalbe da je postupak istraživanja pred Institucijom besplatan i da je podnosilac žalbe i dalje obavezan da koristi sve redovne zakonske procedure i poštuje sve rokove utvrđene odgovarajućim zakonima za korištenje pravnih lijekova pred sudovima ili organima uprave.

Uz žalbu, njen podnosilac prilaže i kopije relevantnih dokumenata koje, za razliku od drugih postupaka, ne moraju biti ovjerene.

Ukoliko u podnesenoj žalbi nedostaje neki od naprijed navedenih elemenata (nepotpuna žalba) ili je žalba nerazumljiva ili sadrži nedostatke koji onemogućavaju postupanje, postupajući pravnik uputiće podnosiocu žalbe bez odlaganja zahtjev za otklanjanje nedostataka u njegovoj žalbi (uz navođenje tih nedostataka i načina na koji se oni mogu otkloniti), i ostaviti podnosiocu žalbe primjeren rok da žalbu dopuni. U slučaju da podnosilac žalbe, u ostavljenom roku ne dostavi svoju dopunjenu žalbu, odnosno dostavi žalbu koja je ponovno nerazumljiva ili nepotpuna, postupajući pravnik pristupiće zatvaranju predmeta.

U skladu sa Pravilima postupka institucije Ombudsmena za ljudska prava Bosne i Hercegovine $^{12}$ ombudsmeni mogu odbiti da prihvate podnesenu žalbu iz nekog od sljedećih razloga, i to:

1) ako je žalba anonimna,

2) ukoliko ombudsmeni ocijene da je žalba zlonamjerna,

3) ako ombudsmeni utvrde da je žalba neosnovana,

4) ako žalba ne sadrži jasan zahtjev podnosioca žalbe,

5) ako se žalbom narušavaju legitimna prava treće strane,

6) ako je žalba podnesena ombudsmenima nakon više od jedne godine od činjenica, događaja ili odluka na koje se žalba odnosi,

7) ako podnosilac žalbe nije iscrpio pravna sredstva, što je od njega bilo razumno za očekivati, 
8) ako je žalba nepotpuna ili nerazumljiva, a podnosilac je nije dopunio, odnosno ispravio na traženje ombudsmena u ostavljenom roku ili je podnosilac odustao od žalbe,

9) ako je žalba u osnovi istovjetna žalbi koja je već razmatrana od strane ombudsmena, a ne sadrži nove relevantne podatke i

10) ako se žalba odnosi na činjenično stanje kakvo je bilo prije 14. decembra 1995. godine.

Ukoliko se utvrdi da postoji neki od navedenih nedostataka, ombudsmeni će donijeti odluku o neprihvatljivosti žalbe, o čemu oni pismeno obavještavaju podnosioca žalbe shodno odredbi člana 28. Pravila postupka Institucije ombudsmena za ljudska prava Bosne i Hercegovine.

Nakon što postupajući pravnik utvrdi da je žalba prihvatljiva, on, u narednoj fazi postupanja po njoj, ispituje njenu osnovanost. Ispitivanje osnovanosti žalbe podrazumijeva provjeru svih navoda koje je podnosilac žalbe precizirao u svojoj žalbi, odnosno činjenica koje je on naveo u žalbi, svakako u kontekstu pojma diskriminacije, odnosno kršenja konkretnog prava žalioca.

Tako će žalba biti neosnovana ako postupajući pravnik u bilo kojem trenutku njenog ispitivanja utvrdi da navodi, odnosno činjenice iz žalbe nisu tačni.

\section{PRETHODNO ISPITIVANJE PRIHVATLJIVOSTI ŽALBE U POGLEDU NAVODA KOJI SE TIČU POSTOJANJA DISKRIMINACIJE}

Imajući u vidu da su Zakonom o zabrani diskriminacije Bosne i Hercegovine jasno definisani elementi diskriminacije, može se konstatovati i da značajan broj osoba koje se Instituciji obraćaju sa svojim pojedinačnim žalbama ne daje dovoljno informacija na osnovu kojih bi se mogla sa sigurnošću utvrditi osnovanost njihovih žalbi. Takođe, veoma često, uz generalno pozivanje na diskriminaciju, žalbeni navodi ukazuju na određene činjenice iz kojih se može zaključiti postojanje povreda nekog drugog prava podnosioca žalbe kao što su to pravo na obrazovanje, pravo na zdravstvenu zaštitu, pravo na pristup socijalnim pravima i slično.

Pitanje utvrđivanja prihvatljivosti podnesene žalbe, podzakonskim aktima Institucije nije posebno uređeno. Međutim, dosljednom implementacijom Pravila postupka institucije Ombudsmena za ljudska prava Bosne i Hercegovine, ombudsmeni su prihvatili međunarodne standarde $u$ pogledu ocjene prihvatljivosti žalbe na osnovu kojih u svim onim predmetima u kojima je vjerovatnoća da se desila povreda određenog prava veća nego da povrede prava nije bilo, ombudsmeni donose odluku da se nastavi sa ispitivanjem konkretne žalbe. Ovi međunarodni standardi omogućavaju ombudsmenima da ispitaju svaku žalbu koja se odnosi na povredu bilo kojeg ljudskog prava ili slobode, odnosno obezbjeđuju mehanizam zaštite u skladu sa najvišim međunarodnim standardima u oblasti ljudskih prava.

Nadalje, u predmetima diskriminacije ombudsmeni postupaju i u skladu sa standardima koji su eksplicitno utvrđeni u ZZD-u, a koji se odnose na tzv. obrnuti teret dokazivanja. U ovom Zakonu, odnosno u odredbi člana 15 ovog zakona koja nosi naziv: Teret dokazivanja, 
evropski standard koji se tiče dokazivanja jednakog postupanja nedvosmisleno je određen ${ }^{13} \mathrm{i}$ on se ogleda u pristupu prema kojem osoba koja se poziva na diskriminaciju mora učiniti vjerovatnim da je došlo do diskriminacije, te učiniti vjerovatnim (odnosno dokazati opravdanu sumnju) da bi zbog nejednakog postupanja moglo doći do diskriminacije, pri čemu teret dokazivanja činjenice da do nejednakog postupanja nije došlo zbog diskriminacije leži na protivnoj strani, odnosno na strani tuženog organa ${ }^{14}$. Dakle, ombudsmeni prilikom ocjene osnovanosti konkretne žalbe primjenjuju standard tereta dokazivanja predviđen u odredbi člana 15. zakona na način da se prilikom istraživanja postojanja konkretne povrede prava ispituje da li se na osnovu navoda iz žalbe može pretpostaviti da je do povrede prava došlo zbog diskriminacije. Rezultat ovakvog načina zaključivanja usmjerava ombudsmene u njihovom daljem postupanju. Shodno tome, ombudsmeni će žalbu:

1) odbaciti - ukoliko je žalba podnosioca očigledno neosnovana u pogledu diskriminacije,

2) uslovno prihvatiti žalbu i od njenog podnosioca zatražiti njenu dopunu u pogledu osnovnih elemenata diskriminacije,

3) žalbu nastaviti ispitivati - u svim onim situacijama kada se može pretpostaviti da se radi o diskriminaciji podnosioca žalbe $\mathrm{i}$

4) nastaviti ispitivati žalbu, ali u odnosu na povredu nekog drugog prava podnosioca žalbe - ako se ne može pretpostaviti da se radi od diskriminaciji, ali se može pretpostaviti da se radi o povredi nekog drugog prava ili osnovne slobode.

Nakon što ombudsmeni, odnosno postupajući pravnik u Instituciji ocijene da žalba ukazuje na moguće kršenje prava podnosioca žalbe, oni pokreću postupak istraživanja na način da od označene odgovorne strane zahtijevaju izjašnjenje na iznesene žalbene navode, odnosno sve neophodne informacije i sve relevantne dokaze, određujući tom prilikom odgovornom organu i rok za dostavljanje odgovora. U ovom trenutku, postupajući pravnik isključivo na osnovu žalbenih navoda može pretpostaviti da se radi o diskriminaciji, odnosno došao je do zaključka da je vjerovatnoća da se diskriminacija desila veća nego da se diskriminacija nije desila. Kao što je već rečeno, prilikom ocjene osnovanosti pokretanja istražnog postupka postupajući pravnik koristi niz pitanja koja su razjašnjena i iz kojih je izveden zaključak o osnovanosti žalbe podnosioca.

U zahtjevu kojim traži izjašnjenje odgovorne strane, postupajući pravnik upoznaje odgovornu stranu sa navodima žalbe, te zahtijeva izjašnjenje odgovorne strane u pogledu istih.

13 Odredba člana 15 Zakona o zabrani diskriminacije koja nosi naslov: Teret dokazivanja glasi: (1) Kada lice ili grupa lica u svim postupcima predviđenim ovim zakonom, na osnovu njima raspoloživih dokaza, učine vjerovatnim da je došlo do diskriminacije, teret dokazivanja da nije došlo do diskriminacije leži na suprotnoj strani. (2) U slučajevima u kojima lice smatra da je snosilo posljedice diskriminacije, kao dokazno sredstvo za ostvarenje prava iz stava (1) ovog člana mogu se koristiti i statistički podaci ili baze podataka. (3) U slučajevima kada lice smatra da je snosilo posljedice diskriminacije zbog propuštanja razumnog prilagođavanja, teret dokazivanja leži na protivnoj strani. (4) Kao svjedok u postupcima za zaštitu od diskriminacije može se pojaviti i lice koje se svjesno izložilo diskriminatorskom postupanju, sa namjerom neposredne provjere primjene pravila o zabrani diskriminacije. (5) Lice iz stava (4) ovog člana dužno je da obavijesti ombudsmene za ljudska prava Bosne i Hercegovine o namjeravanoj radnji, osim ako okolnosti to ne dozvoljavaju, kao i da o preduzetoj radnji izvijesti ombudsmena u pisanoj formi. (6) Sud može lice iz stava (4) ovog člana saslušati kao svjedoka. (7) Lice iz stava (4) može podnijeti tužbu iz člana 12. stav (1) tačka a), b) i d) ovog zakona u konkretnom slučaju. (8) Odredba stava (1) ovog člana ne primjenjuje se u prekršajnim i krivičnim postupcima. (9) U slučaju kada sud razmatra predmet o kojem je Institucija ombudsmena već donijela preporuku, koju strana u postupku koristi kao dokaz, sud je dužan da u skladu sa pravilima postupka razmotri preporuke ombudsmena.

14 Vehabović, F.; Izmirlija, M.; Kadribašić, A., Komentar Zakona o zabrani diskriminacije sa objašnjenjima i pregledom prakse u uporednom pravu, Centar za ljudska prava Univerziteta u Sarajevu, 2010. 
Koristeći posebna pravila dokazivanja u predmetima diskriminacije (shodno ZZD-u), postupajući pravnik upoznaje odgovornu stranu da će se u slučaju propuštanja davanja odgovora na navode iz žalbe, kao i na ocjenu osnovanosti žalbe podnositelja, nastaviti sa razmatranjem žalbe i bez traženog odgovora, jer se može pretpostaviti da se radi o predmetu diskriminacije. Ovo je izuzetno značajno budući da odgovorna strana mora biti upoznata sa posljedicama propuštanja davanja izjašnjenja u pogledu žalbenih navoda.

U zahtjevu za izjašnjenje, postupajući pravnik posebno naglašava da odgovorna strana u svom izjašnjenju, odnosno odgovoru mora da ukaže na objektivnu i razumnu opravdanost radnji koje podnosilac žalbe smatra diskriminatornim, odnosno da objasni razloge svog postupanja u odnosu na navode iz žalbe u pogledu diskriminacije.

U slučaju da izjašnjenje odgovorne strane po žalbenim navodima izostane ili u onim situacijama kada izjašnjenje odgovorne strane nije relevantno sa stanovišta žalbe, postupajući pravnik još jedanput dostavlja odgovornoj strani, odnosno organu tzv. urgenciju za dostavljanje izjašnjenja, odnosno odgovora, naglašavajući u urgenciji potrebu dostavljanja relevantnog odgovora, odnosno pojašnjavajući koje su to posljedice propuštanja dostavljanja traženog izjašnjenja.

Ombudsmeni, odnosno postupajući pravnik, u svakom stadijumu istrage, cijene da li je neophodno izvršiti dodatne radnje koje bi imale za cilj potpuno razjašnjavanje činjenica navedenih u žalbi i izjašnjenju odgovorne strane na žalbene navode. To svakako uključuje uvid u odgovarajuće spise, razgovor sa strankama u postupku, posredovanje među strankama, medijaciju između stranaka i sl.

\section{ZATVARANJE PREDMETA, ODNOSNO DONOŠENJE ODLUKE}

Ombudsmeni za ljudska prava Bosne i Hercegovine ocjenjuju sve činjenice koje su pribavljene u toku istražnog postupka i donose odgovarajuću odluku primjenjujući odgovarajuće testove za konkretne oblike diskriminacije. Shodno tome, ombudsmeni, nakon ocjene svih pribavljenih činjenica utvrđuju da li se radi o određenom obliku diskriminacije.

Ombudsmeni svojom odlukom zatvaraju konkretni predmet u sljedećim slučajevima:

1) ako podnosilac žalbe, bez opravdanog razloga, ne učestvuje u istražnom postupku koji se vodi pred institucijom ombudsmena, i pored valjanog poziva od strane ombudsmena,

2) ako podnosilac žalbe odustane od izjavljene žalbe, a ombudsmeni ne smatraju da treba da nastave vođenje istražnog postupka ex officio,

3) u onim situacijama kada odgovorna strana tokom postupka istrage (svojevoljno) otkloni kršenje prava i sloboda navedenih u žalbi podnosioca,

4) ako strane (odgovorna strana i podnosilac žalbe) postignu sporazumno rješenje,

5) ako je žalba podnosioca neosnovana,

6) ako ombudsmeni nakon sprovedenog istražnog postupka utvrde da postoji neki od razloga za donošenje odluke o neprihvatljivosti izjavljene žalbe, 
7) ako se utvrdi da se ne radi o povredi prava i sloboda koje štite ombudsmeni i

8) ako je preporuka ombudsmena prihvaćena ili kada preporuka nije prihvaćena, a ombudsmen je nakon toga preduzeo radnje u skladu sa Zakonom o ombudsmenu za ljudska prava Bosne i Hercegovine.

Dakle, u svim onim situacijama kada ombudsmeni tokom istrage utvrde da je počinjena povreda prava i sloboda podnosioca žalbe, oni bi trebalo da daju preporuku organima vlasti, odnosno službenicima tih organa. Četiri su osnovna zahtjeva na koja ombudsmeni svojim preporukama odgovaraju, odnosno ombudsmeni mogu donijeti jednu od četiri vrste preporuka ${ }^{15}$, i to:

1) deklaratorna preporuka - ona preporuka kojom se utvrđuje da li se diskriminacija uopšte desila,

2) konstitutivna ili preobražajna preporuka - preporuka kojom se preporučuje odgovornoj strani kako da utvrđenu diskriminaciju otkloni,

3) preporuka sa garancijom neponavljanja - odgovornoj strani daje se preporuka kako da uspostavi efikasan način buduće prevencije ponavljanja,

4) preporuka za naknadu štete - odgovornoj strani daje se preporuka da razmotri zahtjev podnosioca žalbe za naknadu štete, svakako s ciljem prevencije skupih sudskih postupaka.

Deklaratorna preporuka predstavlja preduslov za davanje bilo koje druge preporuke. Ona se može smatrati i najbitnijom od svih navedenih preporuka, jer ombudsmeni za ljudska prava Bosne i Hercegovine u ulozi institucije koja se specijalizovala za oblast ljudskih prava i suzbijanje diskriminacije imaju kapacitet da, na osnovu činjeničnog stanja koje je utvrđeno tokom ispitivanja žalbe izdaju preporuku obrazloženu u skladu sa najvišim međunarodnim standardima u oblasti ljudskih prava i osnovnih sloboda.

15 U Instituciji Ombudsmena u 2016. godini registrovano je ukupno 150 predmeta diskriminacije (u 2015. godini 159, a u 2014. godini 181 predmet). Određeni broj predmeta riješen je pozitivno i prije izdavanja preporuke, bilo posredovanjem, podsticanjem prijateljskog rješenja ili preduzimanjem medijacije između strana u sporu, bilo na način da odgovorni javni organ sam koriguje svoje postupanje nakon prvog obraćanja Instituciji. U 2016. godini Ombudsmeni su izdali 27 preporuka, najčešće u slučajevima mobinga, diskriminacije na osnovu pripadnosti nacionalnoj manjini, na osnovu obrazovanja kao i po ostalim osnovama. Nepoštovanje preporuka Ombudsmena koje se tiču povreda ZZD-a povlači prekršajnu odgovornost fizičkih i pravnih lica, kao i njihovo novčano kažnjavanje do $10.000 \mathrm{KM}$, izricanje mjere bezbjednosti zabrane obavljanja djelatnosti, kao i druge sankcije predviđene čl. 19. i 20. pomenutog Zakona. Institucija Ombudsmena pribjegava pokretanju sudskog postupka samo kao krajnjoj mjeri, jer postoje očekivanja da će preporuke u konačnici biti ispoštovane s obzirom na to da je takvo rješenje $u$ interesu svih strana u postupku.

Najveći broj žalbi u 2016. godini odnosio se na mobing kao poseban oblik diskriminacije na radnom mjestu (55), zatim slijede žalbe na diskriminaciju na osnovu etničke pripadnosti (7), na osnovu polnog izražavanja ili orijentacije (7), diskriminaciju na osnovu nacionalnog ili socijalnog porijekla (6), na osnovu društvenog položaja i pola (5), na osnovu vjere (2), segregacija (2), i po jedna žalba zbog uznemiravanja, diskriminacije po osnovu jezika, veze s nacionalnom manjinom, političkog ili drugog uvjerenja, imovnog stanja i obrazovanja. Prema procjenama Ombudsmena, ovi podaci i dalje ne predstavljaju stvaran prikaz obima diskriminacije, jer i dalje postoje neprijavljeni slučajevi, zbog generalnog nepovjerenja u institucije, kao i zbog straha od eventualnih negativnih posljedica po status žrtava. 
Dakle, nakon što utvrde postojanje diskriminacije u svakom pojedinačnom slučaju, ombudsmeni cijene koja preporuka će se smatrati efikasnom. S druge strane, donesena preporuka mora biti jasna, zatim decidna i ona mora sadržavati zahtjev za preduzimanje konkretne radnje od strane odgovornog organa, odnosno radnje koja vodi otklanjanju utvrđene diskriminacije. Nakon izdavanja preporuke, konkretni predmet se ne zatvara nego on postaje predmetom sistema elektronskog praćenja realizacije preporuka.

Nepostupanje odgovornog organa po izdatim preporukama ombudsmena, odnosno odbijanje saradnje tokom postupka istrage sa ombudsmenima u domenu suzbijanja diskriminacije predstavlja prekršajno djelo za koje je u prekršajnom postupku pred nadležnim osnovnim (opštinskim) sudom moguće izreći značajno visoke novčane kazne. U ovim postupcima, ombudsmeni, a što je izuzetno važno, mogu, a nakon što odgovarajući prekršajni postupak pokrenu, u njemu i učestvovati.

\section{ZAKLJUČAK}

Kvalitet rada bilo kojeg državnog organa zavisi od niza okolnosti, ali su dvije čini se najvažnije: prva podrazumijeva odgovarajući zakonodavni okvir koji definiše njihovo postupanje i druga koja se tiče jačanja institucionalnih kapaciteta navedenih institucija, odnosno ostvarenja svih ljudskih, organizacionih i finansijskih resursa kao pretpostavke za njihovo snažno i efikasno postupanje. Slično stanje je i u ovoj oblasti, s obzirom na to da za efikasnu borbu protiv diskriminacije (ali i svih drugih oblika kršenja ljudskih prava i osnovnih sloboda) nije dovoljno samo usvojiti zakonska rješenja koja su usklađena sa međunarodnim standardima relevantnim za rad organa za zaštitu ravnopravnosti. Ključno je obezbijediti efikasnu i pravilnu primjenu Zakona o zabrani diskriminacije Bosne i Hercegovine, posebno kroz institucionalno jačanje institucije Ombudsmena za ljudska prava Bosne i Hercegovine kao centralne institucije nadležne za zaštitu od diskriminacije u cilju njenog osposobljavanja da efikasno izvršava svoj anti-diskriminatorni mandat. Pri tome, prednje svakako uključuje racionalizaciju procesa donošenja odluka, odnosno adekvatno povećanje finansiranja za kadrovsko jačanje i kampanje podizanja svijesti ${ }^{16}$.

Čini se da kada je Bosna i Herecgovina u pitanju, bez obzira na niz problema sa kojima se susreću gotovo svi organi vlasti, pa tako i ova institucija, ipak, institucija Ombudsmena za ljudska prava Bosne i Hercegovine je na dobrom putu da u narednim godinama postane snažan instrument koji će se baviti pitanjem suzbijanja, odnosno elimininacije svih oblika diskriminacije.

16 Izvještaj Evropske komisije za borbu protiv rasne diskriminacije i netolerancije (ECRI) o Bosni i Hercegovini, 6. decembar 2016. godine. 


\section{LITERATURA}

1. Trnavci, G.; Bešlagić, J., Specifičnosti sudskih postupaka za zaštitu od diskriminacije u Bosni i Hercegovini, Pravni vjesnik, god. 31, br. 3-4, Pravni fakultet u Osijeku, 2015.

2. Vehabović, F.; Izmirlija, M.; Kadribašić, A., Komentar Zakona o zabrani diskriminacije sa objašnjenjima i pregledom prakse u uporednom pravu, Centar za ljudska prava Univerziteta u Sarajevu, 2010.

\section{USTAV, ZAKONI I PODZAKONSKI AKTI}

1. Ustav Bosne i Hercegovine.

2. Zakon o ombudsmenu za ljudska prava Bosne i Hercegovine, Službeni glasnik Bosne i Hercegovine, br. 19/2002, 35/2004 i 32/2006.

3. Zakon o zabrani diskriminacije, Službeni glasnik Bosne i Hercegovine, br. 59/2009 i 66/2016.

4. Zakon o zabrani diskriminacije, Službeni glasnik Republike Srbije, broj 22/2009.

5. Zakon o pučkom pravobranitelju, Narodne novine, br. 76/2012.

6. Zakon o suzbijanju diskriminacije, Narodne novine, br. 85/2008 i 112/2012.

7. Pravila postupka Institucije ombudsmena za ljudska prava Bosne i Hercegovine, Službeni glasnik BiH, broj 104/2011.

8. UN Rezolucija br. 68/171 - Nacionalne institucije za promociju i zaštitu ljudskih prava, decembar 2013.

9. Izvještaj Evropske komisije za borbu protiv rasne diskriminacije i netolerancije (ECRI) o Bosni i Hercegovini, 6. decembar 2016. godine. 


\section{PROCEDURE OF THE INSTITUTION OF HUMAN RIGHTS OMBUDSMAN OF BOSNIA AND HERZEGOVINA IN CASES OF DISCRIMINATION}

\section{Summary}

Human Rights Ombudspersons or national institutions for the protection of human rights in most of modern countries today are independent institutions established with the aim of promoting good governance and the rule of law, as well as protection of human rights and fundamental freedoms. Their jurisdiction includes, as a rule, protection and promotion of human rights and freedoms, as well as the functioning of the national preventive mechanisms for the prevention and the prevention of torture and other cruel, inhuman or degrading treatment or punishment. In addition, the powers of these institutions also cover procedures to be applied in cases involving freedom of access to information, and ministerial, governmental and other appointments. An important segment in functioning of the Ombudsman is the prevention or elimination of discrimination. Discrimination (originating from the Latin word discriminare: separate, distinguish, unwarranted discrimination or unequal treatment, or illegal distinction) is a negative and socially dangerous phenomenon which in a nutshell means any unequal or different treatment including every exclusion, restriction or preference based on real or assumed grounds against any person or group of persons, and their blood relatives or otherwise related to them, on the basis of their race, color, language, religion, ethnicity, disability, age, national or social origin, political or other opinion, property, membership in a trade union or any other association, education, social status and sex, sexual expression or sexual orientation, and any other circumstance with a purpose or a consequence to disable or endanger recognition, enjoyment or exercise on an equal basis, rights and freedoms in all spheres of life. The methods applied in operation of the national bodies for the protection of equality, primarily the Institution of Human Rights Ombudsman of Bosnia and Herzegovina in discrimination cases are subject of this paper.

Keywords: $\quad$ Human rights and freedoms, discrimination, the Institution of Human Rights Ombudsman of Bosnia and Herzegovina, independence in functioning, complaints, procedure for the protection of discrimination.

\section{(1) (5)}

This work is licensed under a Creative Commons

Attribution-NonCommercial 4.0 International License.

Ljubinko Mitrović, PhD, Full Professor, Faculty of Legal Sciences of the Pan-European University APEIRON in Banja Luka and the Human Rights Ombudsman of Bosnia and Herzegovina, Jovana Surutke br. 13, 78000 Banja Luka. E-mail address: 1j.mitrovic@ ombudsmen.gov.ba. ORCID: https://orcid.org/0000-0002-3809-4183. 
